\title{
Correction to: Central nervous system tumors in children under 5 years of age: a report on treatment burden, survival and long-term outcomes
}

\author{
Sarah Metzger ${ }^{1} \cdot$ Annette Weiser $^{1} \cdot$ Nicolas U. Gerber $^{1} \cdot$ Maria Otth $^{1,2} \cdot$ Katrin Scheinemann $^{2,3,4}$. \\ Niklaus Krayenbühl ${ }^{5}$. Michael A. Grotzer ${ }^{1}$ - Ana S. Guerreiro Stucklin ${ }^{1}$ (1)
}

Published online: 28 February 2022

(c) The Author(s) 2022

\section{Correction to: Journal of Neuro-Oncology https://doi.org/10.1007/s11060-022-03963-3}

(1) The first sentence of the subsection Secondary malignancies (in Results) should read as follows:

Three patients were diagnosed with a secondary malignancy during follow-up (Table 2).

(2) In Table 1, the following corrections were required:

(a) the percentage of patients with seizures specified in the last column should be 21.9 (for $n=28$ ).

(b) the total number of patients specified in the last column for Neuroendocrine sequelae should be qualified to include two patients with transient endocrine alterations.

The original article can be found online at https://doi.org/10.1007/ s11060-022-03963-3.

\section{Ana S. Guerreiro Stucklin}

ana.stuecklin@kispi.uzh.ch

1 Division of Oncology and Children's Research Center, University Children's Hospital of Zurich, Zurich,

Switzerland

2 Division of Oncology-Hematology, Department of Pediatrics, Kantonsspital Aarau, Aarau, Switzerland

3 Department of Pediatrics, McMaster Children's Hospital and McMaster University, Hamilton, Canada

4 University of Lucerne, Lucerne, Switzerland

5 Division of Pediatric Neurosurgery, University Children's Hospital of Zurich, Zurich, Switzerland (c) the percentage of LGG patients with Grade 0 hearing deficits should be 84.8 (for $n=39$ ).

Open Access This article is licensed under a Creative Commons Attribution 4.0 International License, which permits use, sharing, adaptation, distribution and reproduction in any medium or format, as long as you give appropriate credit to the original author(s) and the source, provide a link to the Creative Commons licence, and indicate if changes were made. The images or other third party material in this article are included in the article's Creative Commons licence, unless indicated otherwise in a credit line to the material. If material is not included in the article's Creative Commons licence and your intended use is not permitted by statutory regulation or exceeds the permitted use, you will need to obtain permission directly from the copyright holder. To view a copy of this licence, visit http://creativecommons.org/licenses/by/4.0/.

Publisher's Note Springer Nature remains neutral with regard to jurisdictional claims in published maps and institutional affiliations. 